Федотова Тетяна Анатоліївна кандидат економічних наук, доцент кафедри статистики, обліку та економічної інформатики, Дніпровський національний університет ім. О. Гончара, пр. Гагаріна, 72, м. Дніпро, тел.: (050) 732-21-02, https://orcid.org/0000-0002-9529-3429

\title{
ЗАСТОСУВАННЯ СТАНДАРТИЗАЦІЇ В ОСВІТІ ЗАДЛЯ ПІДВИЩЕННЯ її ЯКОСТІ
}

Анотація. Освітня сфера для України - країни, яка вважає себе цивілізованою, є відправною точкою зростання, бо саме тут формується основа суспільного прогресу, наймогутнішій інноваційний ресурс, людський потенціал. Головна їі мета - сформувати модель національної освіти, яка б дала змогу створити могутній освітньо-інноваційний потенціал в країні.

Освітній стандарт затребувався як новий соціально-педагогічний феномен, коли виник попит на упорядковане різноманіття форм, типів і видів освіти. У світі в цілому, і в окремих країнах зростає необхідність у високій освіченості людей нового типу, в адекватній проблемам XXI століття загальнонаціональної і загальносвітової якості освіти, освіти диверсифікованої, але однаково здатної зробити життя людей гідним їх людського статусу.

Останнім часом, поширення одержала розробка стандартів освіти, що є специфікаціями того, якими професійними знаннями й уміннями повинен володіти фахівець. Очевидно, що стандарт професії фіксує тільки результат, що повинен бути досягнутий. Тут виникає складна методологічна і дидактична задача перекладу вимог стандарту професії (спеціальності) на зміст освітнього стандарту.

Нині освітній стандарт стає предметом методологічного, філософського, історичного i педагогічного аналізу. Вітчизняний освітній простір має незначний досвід в процесі запровадження стандартів в освіті, який накопичений багатьма закордонними країнами ще з 1980 років. Розробка механізму стандартизації освіти проходила у рамках національних освітніх систем, що визначило існування різних підходів до стандартизації. Сьогодні процес інтеграції і глобалізації привів до необхідності створення світових стандартів, залучення до їх розробки міжнародних організацій.

Стандартизація в освіті - це модель освіти, іiі міра в упорядкуванні різноманітного освітнього простору. Але головне - це новий спосіб проектування мети в освіті, мети нового типу, що вимагає системної міждисциплінарної рефлексії. Освітній стандарт - оптимістичний симптом, що свідчить про входження освіти в нову освітню епоху - цілісної, ціннісне- 
насиченої, культурозгідної й інтегральної освіти й адекватної їй педагогіки. Освітній стандарт - це норма, що забезпечує наступність навчального плану і навчальної програми, перетворюючі мету в засоби.

Ключові слова: вища освіта, освітній стандарт, якість освіти, освітня система, ВНЗ, державні стандарти освіти.

Fedotova Tetyana Anatoliivna Candidate of Economic Sciences, Associate Professor of Statistics, Accounting and Economic Informatics, Dnipro National University O. Honchara, Gagarina Ave., 72,Dnipro, tel.: (050) 732-21-02, https://orcid.org/0000-0002-9529-3429

\section{APPLICATION OF STANDARDIZATION IN EDUCATION IN ORDER TO IMPROVE ITS QUALITY}

Abstract. The educational sphere for Ukraine - a country that considers itself civilized, is the starting point of growth, because it is here that the basis of social progress, the most powerful innovation resource, human potential is formed. Its main goal is to form a model of national education that would create a powerful educational and innovative potential in the country.

The educational standard was in demand as a new socio-pedagogical phenomenon, when there was a demand for an orderly variety of forms, types and kinds of education. In the world as a whole, and in some countries, there is a growing need for high education of a new type of people, adequate to the problems of the XXI century national and global quality of education, diversified education, but equally able to make people's lives worthy of their human status.

Recently, the development of educational standards has become widespread, which are specifications of what professional knowledge and skills a specialist should have. Obviously, the standard of the profession fixes only the result that must be achieved. Here there is a complex methodological and didactic task of translating the requirements of the standard of the profession (specialty) to the content of the educational standard.

Today, the educational standard is becoming the subject of methodological, philosophical, historical and pedagogical analysis. The domestic educational space has little experience in the process of implementing standards in education, which has been accumulated by many foreign countries since the 1980s. The mechanism of standardization of education was developed within the framework of national educational systems, which determined the existence of different approaches to standardization. Today, the process of integration and globalization has led to the need to create world standards, involve international organizations in their development.

Standardization in education is a model of education, its measure in organizing a diverse educational space. But the main thing is a new way of designing a goal in 
education, a new type of goal that requires systematic interdisciplinary reflection. The educational standard is an optimistic symptom that indicates the entry of education into a new educational era - a holistic, value-rich, culturally appropriate and integrated education and adequate pedagogy. The educational standard is a norm that ensures the continuity of the curriculum and syllabus, turning the goal into a means.

Keywords: higher education, educational standard, quality of education, educational system, universities, state educational standards.

Постановка проблеми. У різних країнах використовуються різні терміни для позначення проектів, моделей (рівнів) освіти (професійні стандарти, державні стандарти освіти, освітні стандарти, специфікації, навчальні плани, навчальні програми і т.п.). Загальним є те, що в цих документах, створюваних на різних концептуальних і методологічних підставах і з неоднаковим правовим статусом, все більшого значення набуває загальнонаціональний (загальнодержавний) вимір. Вони виступають найважливішим початком реальних освітніх процесів, орієнтованих на одержання рівнів знань, умінь, навичок, компетенцій, які підлягають виміру (порівнянню).

Стандарти можуть носити законодавчий характер або бути прийнятими добровільно (соціальними партнерами, навчальними закладами, професійними співтовариствами). Вони можуть являти собою встановлені моделі підготовленості, навчальні програми, погоджені системи вимог і очікувань.

Аналіз останніх досліджень і публікацій. Дослідженню освітніх стандартів, їх взаємозв'язку $з$ рівнем підготовки фахівців та іншим аспектам останнього часу приділено багато уваги дослідниками. Освітній стандарт розглядався $з$ погляду його основних ідей і понять (Беспалько В.П.), аксіології освіти (Зинченко В.П., Нікандров Н.Д.), методологічного аналізу наукового обгрунтування навчання (Краєвський В.В.) формування гуманітарної культури фахівця (Сластьонін В.А.), теоретичних основ змісту загальної середньої освіти (Леднев В.С., Лернер А.Я.), відновлення цілісного характеру освітнього процесу в єдності виховання і навчання (Зімова I.А., Ліхачов Б.Т., Леонтьєв А.А., Мухіна В.С.), структурно-змістовних характеристик освіти (Дикий Ю.І., Леднев В.С., Шішов С.Е.), загально-педагогічних аспектів теоретичних основ проектування стандартів (Соколов В.М.), науково-педагогічних основ формування стандартів освіти (Бєляєва А.П., Варданян Ю.В., Коропів В.В., Кузьміна Н.В., Лейбович А.Н., Мухаметзянова Г.В., Новиков А.М., Семушіна Л.Г., Смірнов І.П. та ін.), філософії освіти і формування освітньої політики (Шадріков В.Д.), загальнометодологічних підходів до стандартизації в освіті (Субетто А.I,), правового забезпечення (Буслов Е.В., Кудрявцев Ю.А., Смолін О.Н., Шкатулла В.І.).

Ще раніш, на початку 80-х рр., ідея освітнього стандарту зароджується в закордонній освітній практиці, педагогіці і філософії освіти. В даний час в Україні відомі підходи до стандартизації в освіті таких закордонних 
дослідників, як Батюшко B.I., Галко Т.Е., Грутингс П., Крайтон I., Лис Н.I., Равич Д., Рощінська О.М., Стабс У., Ткалеч В., Хиллз Г., Шмідт Г.В., Яниш Б. та ін.

Незважаючи на те, що дослідженню питань реформування системи вищої освіти, рівню підготовки фахівців та іншим аспектам приділено багато уваги дослідниками, освітня система має ще багато проблем і невирішених питань, зокрема в частині модернізації національної системи вищої освіти у зв'язку 3 рівноцінним включенням в світові систему.

Мета статті - визначення і пропонування нової технології розробки освітніх стандартів.

Виклад основного матеріалу. Поняття $i$ сутність освітнього стандарту. Відповідно до ст. 10 Закону України "Про вищу освіту" стандарт вищої освіти - "це сукупність вимог до освітніх програм вищої освіти, які $є$ спільними для всіх освітніх програм у межах певного рівня вищої освіти та спеціальності" [1].

Поряд 3 відзначеними новими в порівнянні 3 навчальним планом i навчальною програмою якісними характеристиками, освітній стандарт являє собою інтеграцію таких загально-педагогічних категорій як цілі, цінності, зміст, форми і засоби освіти. У цьому сенсі стандарт може бути інтерпретований як синтетична категорія загальної педагогіки, що вимагає для свого розуміння міждисциплінарного, системного, цілісного підходу.

Стандарт описує завдання, виконувані в рамках конкретної професійної діяльності, а також відповідні знання, вміння, навички.

Державні освітні стандарти з'явилися значним кроком на шляху додання системі підготовки фахівців нових якостей, відходу від уніфікації, включення ресурсів автономності, академічних свобод і більш ліберальних підходів до проектування змісту освіти. Проте в них ще закладено багато напрямків їхнього майбутнього удосконалювання.

Професійна освіта, на думку Ж. Делора, «...не уникла того розмаху і тієї терміновості, з якими проявилася на політичному рівні необхідність проведення реформи освіти з метою задоволення потреб економічного характеру» $[2$, с. 36].

Стрімко актуалізувалася проблема поглиблення зв'язків освіти зі світом праці. «...Випускникам, - говориться в Програмному документі ЮНЕСКО, прийдеться зштовхнутися з необхідністю зміни роботи, відновлення своїх знань і одержання нової кваліфікації. Світ праці радикально міняється, і велика частина знань, що студенти здобувають у ході своєї первісної підготовки, швидко застаріває. Постійні й інтерактивні партнерські зв'язки з виробничим сектором мають найважливіше значення і повинні включатися в загальні задачі i діяльність навчальних закладів. Однак варто підкреслити необхідність розгляду зв'язків освіти зі світом праці в довгостроковій перспективі й у широкому плані» [3, с. 29].

Аналіз ефективності діючої системи освітніх стандартів та ії недоліки. Сьогодні усе більшого значення набуває співробітництво між навчальними 
закладами i роботодавцями, тому що перші поставлені перед необхідністю прогнозування потреб ринку праці 3 метою якісного перспективного планування процесу навчання, а другі зацікавлені в підвищенні якості професійної освіти майбутніх працівників.

Це важливо ще і тому, що традиційні навчальні програми вже досить застаріли, вони не відповідають сьогоднішнім вимогам ринку праці. Раніше діюча система організації навчання була цілком у руках центральних державних планових комітетів, що були відповідальні також за централізований розвиток навчального плану. Зараз же вищі навчальні заклади повинні самостійно розробляти свої навчальні плани і програми з урахуванням вимог державних стандартів. Тому на сьогодні постає завдання корінних змін змісту цих програм. Проте, освітні установи володіють певною матеріальною базою, котру не можна відразу обновити конкретними кадрами, які неможливо перенавчити за дуже короткий час, а також стереотипами підготовки, які не представляється можливим швидко перебудувати.

Ринки праці сьогодні найчастіше вимагають низько-кваліфіковану робочу силу, для якої не потрібна серйозна професійна підготовка. I якщо система освіти буде суворо відповідати ринковим потребам, це може призвести до різкого зниження професійної майстерності випускників, зниженню кваліфікаційного рівня підготовки [4, с. 21]. Безсумнівно, необхідна випереджальна професійна освіта. Якщо ми маємо справу 3 довгостроковою тенденцією затребуваності низько-кваліфікованої праці, то ефективність діючої системи освітніх стандартів буде залишатися низькою. Проте слід враховувати суперечливість потреб ринку праці, про що говорять закордонні експерти.

Маргрет Кунцман, Уте Лаур-Ернс та інші пишуть у посібнику «Розробка стандартів в області професійної освіти»: «Багато країн..., що проходять через процес корінного переструктурування й економічний розвиток яких ще вкрай хитливий, зіштовхуються 3 важкорозв'язною проблемою: яку форму повинні прийняти освітні стандарти (їх зміст, тривалість дії, рівень) в умовах, коли ще не відомо, які сектори економіки одержать позитивний розвиток і на які види спеціальностей (кваліфікацій) виникне попит на ринку праці? На які професії виникне значний попит у майбутньому? Які види навчання повинні одержати молоді люди?... 3 іншого боку, вони також не можуть просто вичікувати, нічого не роблячи, не розробляючи нових стандартів чи просто використовуючи старі... Таким чином, потрібно зробити «первинний вибір» $\mathrm{i}$ прийняти важливе рішення, цілком віддаючи собі звіт у тому, що належним образом оформлені стандарти потрібно буде переглянути або навіть цілком замінити усього лише через кілька років. Це практично неминуче» [5, с. 24].

Експерти Всесвітнього банку А. Адамс, Д. Мідлтон і А. Зайдерман у своїй статті в журналі ЮНЕСКО «Перспективи. Питання освіти» справедливо зауважують: «Більш тісне ув'язування економічної й освітньої політики, а також диверсифікованість виділених на освіту коштів повинні доповнюватися 
заходами для удосконалення гнучкості державних структур навчання, їхньої результативності» [6, с. 18].

В іншому місці вони пишуть: «... При наявності можливостей працевлаштування після одержання підготовки i при ув'язуванні сфери навчання зі сферою зайнятості віддача від вищої школи може бути вище віддачі від загальноосвітньої системи навчання» [6, с. 22].

Узагальнимо сильні і слабкі сторони освітніх стандартів, а також їх можливості і загрози в якості підготовки спеціалістів (табл. 1).

Таблицуя 1

SWOT-аналіз державних стандартів освіти

\begin{tabular}{|c|c|}
\hline $\begin{array}{l}\text { Сильні сторони } \\
\text { 1. Соціально-ціннісна } \\
\text { орієнтація випускників } \\
\text { 2. Наявність елементів широко } \\
\text { профільної підготовки і базових } \\
\text { навичок } \\
\text { 3. Подолання } \\
\text { технократизму й утилітаризму } \\
\text { 4. Установка на розвиток } \\
\text { особистості вако } \\
\text { 5. Відхід від жорсткої } \\
\text { галузевої прихильності } \\
\text { 6. С. Сполучення } \\
\text { загальноосвітньої і професійний } \\
\text { освітніх програм }\end{array}$ & $\begin{array}{l}\text { Слабкі сторони } \\
\text { 1. Декларативний, когнітивний характер вимог } \\
\text { 2. Відсутність розвитої системи загальних, специфічних і } \\
\text { конкретних цілей } \\
\text { 3. Слабкий оціночно-діагностичний потенціал } \\
\text { 4. Усічена (скорочена) загальноосвітня підготовка } \\
\text { 5. Відсутність інтегрованої (безупинної) підготовки на } \\
\text { всіх рівнях } \\
\text { 6. Нерозвиненість модульних технологій } \\
\text { 7. Орієнтація на академічні традиційні показники } \\
\text { ефективності освітнього процесу } \\
\text { 8. Перевага «процесуальних» параметрів }\end{array}$ \\
\hline $\begin{array}{l}\text { 1. Доступ в освітні установи, } \\
\text { що реалізують програми більш } \\
\text { високих рівнів (ступіней) } \\
\text { 2. Полегшення адаптації в } \\
\text { умовах вузькоспеціалізованого } \\
\text { виробництва або сфери } \\
\text { діяльності (на першому етапі } \\
\text { трудової діяльності) }\end{array}$ & $\begin{array}{l}\text { Погрози } \\
\text { 1. Ускладнення або важка досяжність професійної } \\
\text { мобільності } \\
\text { 2. Відсутність саморефлексії випускника щодо дійсного } \\
\text { рівня своєї підготовки } \\
\text { 3. Формування ілюзорних домагань випускників в } \\
\text { умовах когнітивної спрямованості освіти } \\
\text { 4. Обмеження переважно вузькопрофесійними } \\
\text { навичками } \\
\text { 5. Відсутність мотивації до зміни діяльності в умовах } \\
\text { невизначеності } \\
\text { 6. Абстрактність вимог } 3 \text { погляду їх релевантності } \\
\text { конкретним (регіональним) ринкам праці } \\
\text { 7. Орієнтація на традиційні форми і технології освітнього } \\
\text { процесу }\end{array}$ \\
\hline
\end{tabular}

Однієї з першочергових задач на початковій стадії реалізації проекту відновлення $\epsilon$ аналіз ринків праці, а також вибір на основі аналізу професій, спеціальностей і спеціалізацій, що у найбільшій мірі відповідають запитам місцевих і регіональних ринків праці [7]. 
У цьому напрямку можна виокремити чотири типи проблем:

- відсутність необхідних кваліфікацій (знань, умінь, навичок, компетенцій);

- дефіцит необхідних фахівців [8];

- часткове використання кваліфікацій випускників;

- перевищення пропозиції над попитом.

Безсумнівно, ці проблеми в різній мірі мають відношення до профілів підготовки і змісту вищої освіти.

Концеептуальна модель удосконалення освітніх стандартів, навчальних планів $i$ програм. Етап концептуального моделювання займе досить тривалий період. По-перше, необхідно знайти напрямок удосконалення, що буде враховувати національні особливості вищої освіти в Україні під час наближення до міжнародних стандартів. Важливо задіяти весь інноваційний ресурс державних стандартів. Необхідна ретельна інвентаризація стандартів першого покоління 3 погляду ідей модернізації освіти i даних аналізу національного і регіонального ринків праці. Отже, в певній мірі зберігаючи культуру освітнього стандарту, що сформувалася в Україні, необхідно створити новий тип проектування освіти. В даному напрямку нами пропонуються наступні стратегічні заходи.

По-перше, вітчизняні i закордонні експерти цілком погодилися 3 висновком ЮНЕСКО про те, що розвиток освіти «... не може бути... реалізований в рамках жорстких чи нав'язаних структур», що в наявності «провал стратегій розвитку, заснованих на простому копіюванні або нав'язуванні ... моделей», що «...усе більше людей і установ приходять до розуміння того, що у всіх регіонах пряме запозичення іноземних концепцій i цінностей i iгнорування регіональних i національних культур i філософіï спричиняють негативні наслідки для освіти» [6, с. 27].

По-друге, необхідно залучити до роботи висококваліфікованих методистів як на міністерському рівні, так і з представників навчальних закладів регіонів.

По-третє, необхідно забезпечити широку популяризацію даного проекту.

По-четверте, обрати пілотні заклади, в яких протягом одного навчального року відбудеться експериментальна стадія нової моделі стандартів освіти.

Робота $з$ удосконалення державних стандартів, навчальних планів і програм, уточнення концептуально-методичних основ для створення стандартів професійної освіти нового покоління, освоєння нових процедур і механізмів їхньої розробки і реалізації, розширення складу суб'єктів розробки - усе це може зробити свій конструктивний вплив на удосконалення практики стандартизації в сфері удосконалення підготовки фахівців і підвищення їі якості.

Для того, щоб наша система освіти була визнана ефективною, в процесі іiі застосування повинні вирішуватися, на нашу думку, чотири основні завдання.

По-перше, система повинна чітко диференціювати рівень знань студентів, враховувати ступінь засвоєння матеріалу кожним. 
По-друге, стимулююча роль системи освіти повинна проявлятися в здатності виявляти більш талановитих молодих людей, сприяти через засвоєння змісту важливих дисциплін формуванню студента як творчої особистості i висококваліфікованого фахівця.

По-третє, слід встановити повну і критеріальну об'єктивність оцінки рівня i якості оволодіння знаннями під час навчання.

По-четверте, необхідно розроблення системи, яка б давала можливість перезарахування предметів при переході 3 одного закладу до іншого, незважаючи на специфіку викладання окремих курсів в різних навчальних закладах і різне часове навантаження навчальних дисциплін.

Кожний працівник освітньої системи може дати однозначну відповідь, що існуюча сьогодні система не виконує ці завдання4.

Крім того, у своєму нинішньому вигляді система оцінювання не тільки не стимулює, а навпаки, дестимулює досягнення високих результатів в навчанні. Особливо це проявляється на заочній формі навчання, де для більшості заочників "задовільно" є основою, і нерідко - єдиною оцінкою 3 багатьох дисциплін.

У сучасних умовах все більшого значення набуває самостійність ВН3, здатність адекватно реагувати на вимоги часу. У кожній країні склалося своє співвідношення впливу держави на діяльність системи освіти i, власне, відповідальності керівництва та академічної громади університету [9, с. 127]. Така ситуація зумовлена всім комплексом факторів впливу і рівнем розвитку в суспільстві демократичних цінностей, традиціями, законодавством в суміжних сферах - фінансово-господарській, земельній, права власності і, звичайно, науковій i освітянській. Використати досвід якоїсь країни, перенести лише окремі елементи неможливо, бо їх система взаємозв'язків складалася поступово протягом багатьох десятиліть.

Аналізуючи національні нормативні акти про освіту на різних рівнях можна стверджувати, що в країні вдалося створити певну систему автономності.

Реалізуючи принципи автономії на практиці слід уникати що найменш двох перекосів. По-перше, не слід сприймати університетську автономію як надання привілеїв окремим університетам, виходити 3 наявності реальних умов у суспільстві і готовності академічної громади університету. По-друге, - щоб автономія від міністерства не призвела до диктатури окремих груп чи керівника закладу, що ми іноді спостерігаємо в скаргах представників колективу окремих університетів.

Автономія передбачає більшу самостійність університетів в організації навчально-виховного процесу, у вирішенні питань стратегічного розвитку університету, у фінансово-господарській діяльності тощо. Але вона водночас означає розширення академічних свобод, розвиток університетського самоуправління, зростання впливу професорсько-викладацького складу на 
прийняття рішень, підконтрольність університетської адміністрації академічній громадськості і, крім того, - більшу відповідальність університету за результати діяльності.

Висновки. Нова якість освіти буде досягатися також через зближення освіти і науки, яка має стати основою розвитку академічної вищої освіти. Університетська наука потребу суттєвих змін в нових умовах. Конче необхідно підвищення ролі університетської науки як у розвитку суспільства в цілому, так і в освітянській діяльності зокрема. У нас не повинно бути університетів, де відсутні серйозні наукові дослідження. Це вже не $є$ за рівнем університетом. У зв'язку з цим слід суттєво, в кілька разів, збільшити фінансування науки у вищій школі. I взагалі, потребує перегляду статус ВНЗ, освіти і науки в інноваційному розвитку України.

Протягом останнього часу відбулися зміни у законодавчій і нормативній базі вищої освіти, розроблено і схвалено державні програми щодо розвитку вищої світи, комп'ютеризації вищих навчальних закладів i оновлення матеріально-технічної бази, моніторингу якості оцінки. Затверджено концептуальні засади розвитку вищої технічної, педагогічної освіти та їх інтеграції в європейський освітній простір. Поліпшилася фінансова ситуація в системі вищої освіти і науки: підвищено заробітну плату науковим і науковопедагогічним працівникам та розмір стипендії студентам; прийнято важливе урядове рішення про пільги на проїзд громадським транспортом для студентів незалежно від джерела фінансування їх навчання тощо.

Під кінець необхідне зазначити, що всі розглянуті в роботі питання щодо модернізації національної системи вищої освіти, так чи інакше пов'язані 3 виконанням зобов'язань України як країни - учасника Болонського процесу.

\section{Лimepamypa:}

1. Про вищу освіту. Закон України від 1.07.2014 p. N № 1556-VII. k [in Ukrainian]

2. Кривонос Р. А. Делор Жак. Українська дипломатична енциклопедія: У 2-х т. / Редкол.: Л. В. Губерський (голова) та ін. - К: Знання України, 2004. - Т.1 - 760 с.

3. Реформа и развитие высшего образования. Программный документ. ЮНЕСКО, 2004.

4. Профессиональное образование в XXI веке. Материалы второго международного конгресса по техническому и профессиональному образованию. Львов, 26-30 апреля 2004 г. Автор составитель Олейникова О.Н. Львов, 1999. 84 с. k [in Ukrainian]

5. Кастро Клаудио де Мора. Политика Всемирного Банка: объединение усилий. Перспективы // Вопросы образования. Ежеквартальный журнал ЮНЕСКО. № 22001 (82), c. $25-34$.

6. Адамс Арвил В., Мидлтон Джон, Зайдерман Адриан. Доклад Всемирного Банка о политике в области профессионального образования. Перспективы // Вопросы образования. Ежеквартальный журнал ЮНЕСКО. № 21999 (82), с. 7-25.

7. The impact of labour marßet information on vocational education and training standards. Advisory Forum. Subgroup C. ETF-AF99-001. 38 p.

8. Хомишин I. Сучасний стан стандартизації вищої освіти в Україні // Вісник Національного університету «Львівська політехніка». Серія: Юридичні науки. № 8762017. c. $205-209$. 
9. Стандартизація професійної освіти: теорія і практика; монографія / А. А. Каленський, П. Г. Лузан, Н. М. Ваніна, Т. М. Пащенко, С. Г. Кравець, Т. В. Пятничук. За наук. ред. А. А. Каленського. - Житомир: «Полісся», 2018.- 256 с.

10. Панич О. Система підготовки стандартів вищої освіти і перспективи іiі вдосконалення // Портал "Освітня політика" http://education-ua.org/ua/articles/1324-sistemapidgotovki-standartiv-vishchoji-osviti-i-perspektivi-jiji-vdoskonalennya.

\section{References:}

1. Pro vishhu osvitu [About higher education]. Zakon Ukraïni vid 1.07.2014 r. № 1556-VII [in Ukrainian].

2. Krivonos, R. A. Delor, Zhak (2004). Ukraïns'ka diplomatichna enciklopedija [Ukrainian diplomatic encyclopedia]: U 2-h t. / Redkol.: L. V. Gubers'kij (golova) ta in. - K: Znannja Ukraïni, T.1, 760. [in Ukrainian].

3. Reforma i razvitie vysshego obrazovanija (2004) [Reform and development of higher education]. Programmnyj dokument. JuNESKO [in France].

4. Professional'noe obrazovanie v XXI veke (1999)[ Vocational education in the XXI century]. Materialy vtorogo mezhdunarodnogo kongressa po tehnicheskomu i professional'nomu obrazovaniju. L'vov, 26-30 aprelja 2004 g. Avtor sostavitel' Olejnikova O.N. L'vov, 84 [in Ukrainian]

5. Kastro Klaudio de Mora (2001). Politika Vsemirnogo Banka: ob\#edinenie usilij. Perspektivy // Voprosy obrazovanija. Ezhekvartal'nyj zhurnal JuNESKO - Education issues. UNESCO Quarterly Journal. № 2 (82), s. 25-34 [in France].

6. Adams, Arvil V., Midlton, Dzhon, Zajderman ,Adrian (1999). Doklad Vsemirnogo Banka o politike v oblasti professional'nogo obrazovanija. Perspektivy [World Bank Vocational Education Policy Report. Perspectives] // Voprosy obrazovanija.. Ezhekvartal'nyj zhurnal JuNESKO Education issues. UNESCO Quarterly Journal, 2 (82), 7-25[in France].

7. The impact of labour marßet information on vocational education and training standards. Advisory Forum. Subgroup C. ETF-AF99-001. 38 p. [in France]

8. Homishin,I. ( 2017) Suchasnij stan standartizaciï vishhoï osviti v Ukraïni [The current state of standardization of higher education in Ukraine] // Visnik Nacional'nogo universitetu "L'vivs'ka politehnika». Serija: Juridichni nauki - Bulletin of the National University "Lviv Polytechnic". Series: Legal Sciences. № 876. s. 205-209 [in Ukrainian].

9. Standartizacija profesijnoï osviti: teorija i praktika; monografija (2018) [Standardization of vocational education: theory and practice] / A. A. Kalens'kij, P. G. Luzan, N. M. Vanina, T. M. Pashhenko, S. G. Kravec', T. V. Pjatnichuk. Za nauk. red. A. A. Kalens'kogo. Zhitomir: «Polissja», [in Ukrainian].

10. Panich, O. Sistema pidgotovki standartiv vishhoï osviti i perspektivi iii vdoskonalennja [The system of preparation of higher education standards and prospects for its improvement] // Portal "Osvitnja politika - Portal "Education Policy". Retrieved from http://educationua.org/ua/articles/1324-sistema-pidgotovki-standartiv-vishchoji-osviti-i-perspektivi-jijivdoskonalennya [in Ukrainian]. 